\title{
Studies reducing the $\mathrm{H}_{2} \mathrm{~S}$ from natural gas of using polyimide membrane
}

\begin{abstract}
A laboratory pressure system with a membrane module was set up allowing to perform flow measurements and separation of gases and vapors. At the membrane polyimide module permeability test was conducted four mixes $\mathrm{CH}_{4}-\mathrm{H}_{2} \mathrm{~S}$ concentrations ranging from $0.28 \%$ to $17.9 \% \mathrm{H}_{2} \mathrm{~S}$, with different ratios of the permeate flow to the retentate inlet pressures in the range

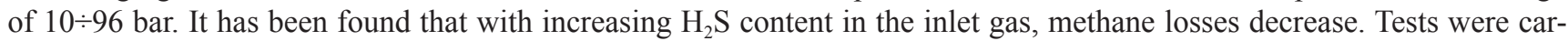
ried out for different inlet gas flows at breakdown coefficients in the range of $0.08 \div 0.45$. The study was conducted in a high pressure, aggressive environment for highly toxic gases. The article shows the possibility of changing the composition of product streams in the conducted membrane separation process. Three times the hydrogen sulfide content in the permeate was increased. The degree of $\mathrm{H}_{2} \mathrm{~S}$ removal from the inlet gas was up to $90 \%$. It has been found that membrane techniques can be successfully used in the preliminary stage of the natural gas sweetening process.
\end{abstract}

Key words: membrane modules, gas separation, polyimides, hydrogen sulphide, natural gas.

\section{Określenie możliwości separacji siarkowodoru ze strumienia gazów na membranach poliimidowych}

\begin{abstract}
Zestawiono laboratoryjną instalację ciśnieniową z modułem membranowym pozwalającą wykonywać pomiary przepływu i separacji gazów i par. Na module z membranami poliimidowymi przeprowadzono badania przepuszczalności czterech mieszanek $\mathrm{CH}_{4}-\mathrm{H}_{2} \mathrm{~S}$ o stężeniach od $0,28 \%$ do $17,9 \% \mathrm{H}_{2} \mathrm{~S}$, przy różnych stosunkach przepływu permeatu do retentatu dla ciśnień wlotowych w zakresie 10 $\div 96$ bar. Stwierdzono, że ze wzrostem zawartości $\mathrm{H}_{2} \mathrm{~S}$ w gazie wlotowym, maleją straty metanu. Testy prowadzone były dla różnych przepływów gazu wlotowego przy współczynnikach podziału na strumienie w zakresie $0,08 \div 0,45$. Badania prowadzono w wysokociśnieniowym, agresywnym środowisku dla gazów wysokotoksycznych. W artykule wykazano możliwość zmiany składu strumieni produktowych w prowadzonym procesie separacji membranowej. Uzyskano trzykrotny wzrost zawartości siarkowodoru w permeacie. Stopień usunięcia $\mathrm{H}_{2} \mathrm{~S}$ z gazu wlotowego dochodził do $90 \%$. Stwierdzono, że techniki membranowe mogą z powodzeniem być zastosowane we wstępnym etapie procesu odsiarczania gazu ziemnego.
\end{abstract}

Słowa kluczowe: moduły membranowe, separacja gazów, poliimidy, siarkowodór, gaz ziemny.

Due to their structural, economic and environmental advantages, membrane techniques have the potential to replace or supplement some of the sorption methods used to date for the separation of gaseous components. INiG - PIB has been undertaking research in this field by conducting e.g. tests of the separation of natural gas components on a polyimide membrane $[19,33]$. Subsequent tests have shown that it is possible to reduce the contents of $\mathrm{N}_{2}, \mathrm{CO}_{2}$ and $\mathrm{H}_{2} \mathrm{O}$ in the gas and the high effectiveness of the removal of moisture from the gas on this membrane makes it possible to completely replace other more expensive drying methods [20]. This paper undertakes to determine the possibility of separating hydrogen sulphide from gas on polyamide membranes.

$\mathrm{H}_{2} \mathrm{~S}$ content of the commercial gas is defined in Poland at $7 \mathrm{mg} / \mathrm{Nm}^{3}$ [37]. Achieving such a low level in one technological operation is possible only by means of chemical sorption methods, which are expensive in terms of investment and operation $[16,22,29]$. In this study, tests were carried out to isolate the hydrogen sulphide parts from natural gas by membrane separation method, which is characterised by very low operating costs.

Membrane separation of gaseous components is usually carried out by means of non-porous membranes [6, 23], where 
the gas is adsorbed on the membrane surface and then diffuses across the barrier and desorbs on the other low-pressure side of the membrane as a permeate. The inlet gas stream loses the components that pass through the membrane faster after a contact with the membrane and is referred to as the retentate at the outlet. The separation of components is possible due to their permeability being different, which allows for obtaining two gas streams with different compositions. The permeability ratio of the two components is determined by selectivity (selectivity coefficient, separation coefficient).

The actual separation of the components is also influenced by the macroscopic factors related to the structure of the membrane modules, such as the contact time of gas at the highpressure side with the membrane surface. The stream of gas flowing into the membrane module $-F$ is separated from the stream passing through the membrane (permeate) $-N$. The ratio of the volume of the permeate $(\mathrm{N})$ to the volume of the inlet gas is defined as the stage cut $\Theta$ :

$$
\Theta=N / F
$$

The selection of membrane consists in the application of such a membrane in which the separation of selected gas components will be as high as possible, with the permeate stream being of a satisfactory size. The lower stage cut $\Theta$ is, the more economical the expected effect of separation of the gaseous mixture into two streams is.

Membrane modules used for gas separation can have different designs. They can have a frame, plate, spiral-wound or tubular (including capillary) structures [4]. In industrial gaseous component separation processes, the most common types of modules are those with spiral-wound and capillary hollow-fibre membranes [24, 32, 35].

The effectiveness and economy of the membrane separation of gaseous mixtures result from the properties of the used membrane (permeability and selectivity) and the gas flow rate $[12,17,18]$. If the application of membrane separation is aimed at lowering the mass content of $\mathrm{H}_{2} \mathrm{~S}$ in the gas, if it is a part of the technology for natural gas desulphurisation, i.e. the removal of e.g. $60 \div 90 \% \mathrm{H}_{2} \mathrm{~S}$ from its stream, it has a serious economic justification [7, 31].

Acidic component separation methods using membranes have been in use for almost forty years. The commercialisation of most membrane tests has focused on the removal of carbon dioxide from natural gas and the mechanisms of $\mathrm{H}_{2} \mathrm{~S}$ permeation through membranes have been less investigated. The main reasons for this were the highly toxic and corrosive properties of this gas $[14,22,26,28]$. Laboratory tests on the separation of $\mathrm{H}_{2} \mathrm{~S}$ from natural gas were started in published articles $[6,10$, $21,25,31]$ by pilot tests on the separation of $\mathrm{H}_{2} \mathrm{~S} / \mathrm{CH}_{4}$. Most of the results presented in the subsequent studies were related to membranes made of cellulose acetate (CA) [1-3], polyimide $[11,25,27,36]$, polyurethane [8, 23, 25] and Pebax [32]. Many studies concerned the modifications of polymer chains by promoting or inhibiting various function groups to achieve higher values of selectivity and permeability of the membranes made of these polymers [35]. Some publications refer to the modifications of polyimide membranes [9, 30], which are an attractive class of polymers and have a number of advantages (plasticisation resistance and swelling resistance) and high mechanical strength to high pressure differentials [11, 34, 36].

\section{Test stand}

The tests of the reduction of $\mathrm{H}_{2} \mathrm{~S}$ in natural gas were performed using a hollow-fibre capillary membrane module manufactured by UBE Industries (Japan). The membrane made of polyimide placed in the module is an example of an asymmetrical dense-porous membrane, which is shown in Figure 1.

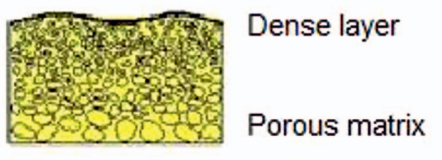
Fig. 1. A section through the UBE polyimide membrane tested as part of laboratory tests [34]

These membranes are characterised by a unique structure resulting from the different length of the polymer chain with variable porosity in the cross-section. The module is placed in a high-pressure steel housing designed for counter-current stream flows, as shown in Figures 2 and 3.

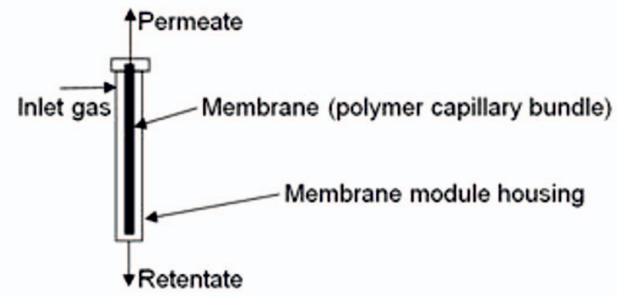

Fig. 2. The diagram of the membrane module in a countercurrent system - one product stream (the permeate passing through the membrane) flows in the opposite direction to the other product stream (retentate)

The membrane module was the main part of the measuring system, which was equipped with flow and pressure control valves, thermometers and flow meters. The gas flowing into the module flowed into the space between the capillary membranes. The gas inlet was located on the permeate stream collection side (counter-current system). 


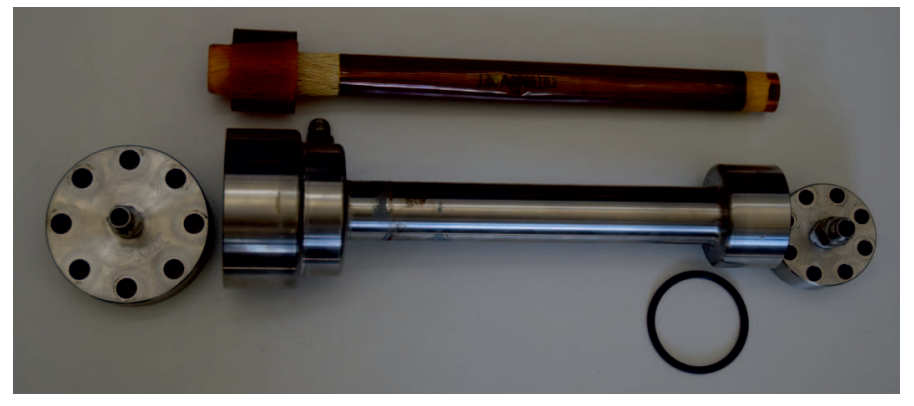

Fig. 3. A photo of a hollow-fibre membrane bundle and a module housing for membrane separation

The gas separation tests of four different concentrations of hydrogen sulphide in methane were carried out on a membrane module supplied with gas from a cylinder. The mixtures of gases were prepared in INiG - PIB from pure components $\left(>99.9 \%\right.$ ) by pumping them successively (first $\mathrm{H}_{2} \mathrm{~S}$ ) in appropriate proportions into a hydrogen sulphide resistant to cylinder.

The system is equipped with gas regulators, ball (shut-off) valves, control valves and flow meters. A diagram of the system is shown in Figure 4.

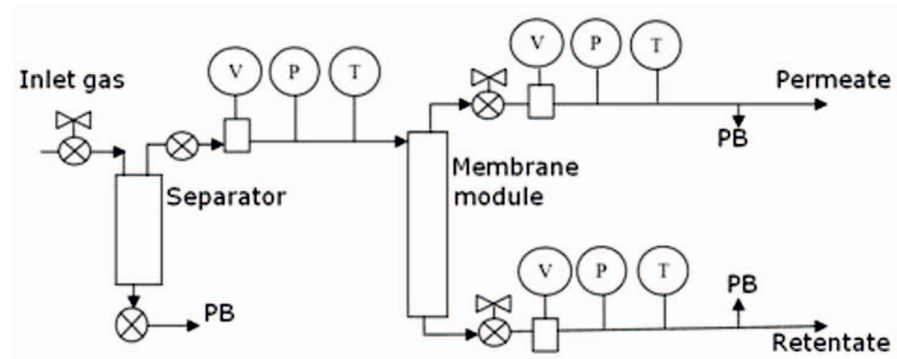

Fig. 4. The diagram of the system for testing the separation of methane - hydrogen sulphide mixture on a membrane module. Symbols: $\mathrm{PB}$ - sampling point, $\mathrm{V}$ - flow meters, $\mathrm{P}$ - pressure gauges, $\mathrm{T}-$ thermometers

The gas from the cylinder was directed to a small separator, which also performed the role of a pressure stabiliser (buffer), and then flowed through a needle valve into a flow meter whose readings were sent to a computer, where the current gas flow rate in $1 /$ min was read in appropriate software. The current gas pressure and temperature values were read before the inlet into the membrane module. Pressure and temperature were measured again in the high-pressure product stream, and its flow rate was regulated by another regulator, behind which a pipette for collecting the sample for analysis was placed. The PVT measurements of the permeate stream were performed in a similar manner.

The configuration of the gas separation test stand containing a polyimide membrane module is shown in Figure 5. The regulation of the retentate outflow through the regulator and the needle valve made it possible to obtain different stage cut $(\Theta)$ values, which were calculated by simultaneous measurement of inlet gas, permeate and retentate flows.
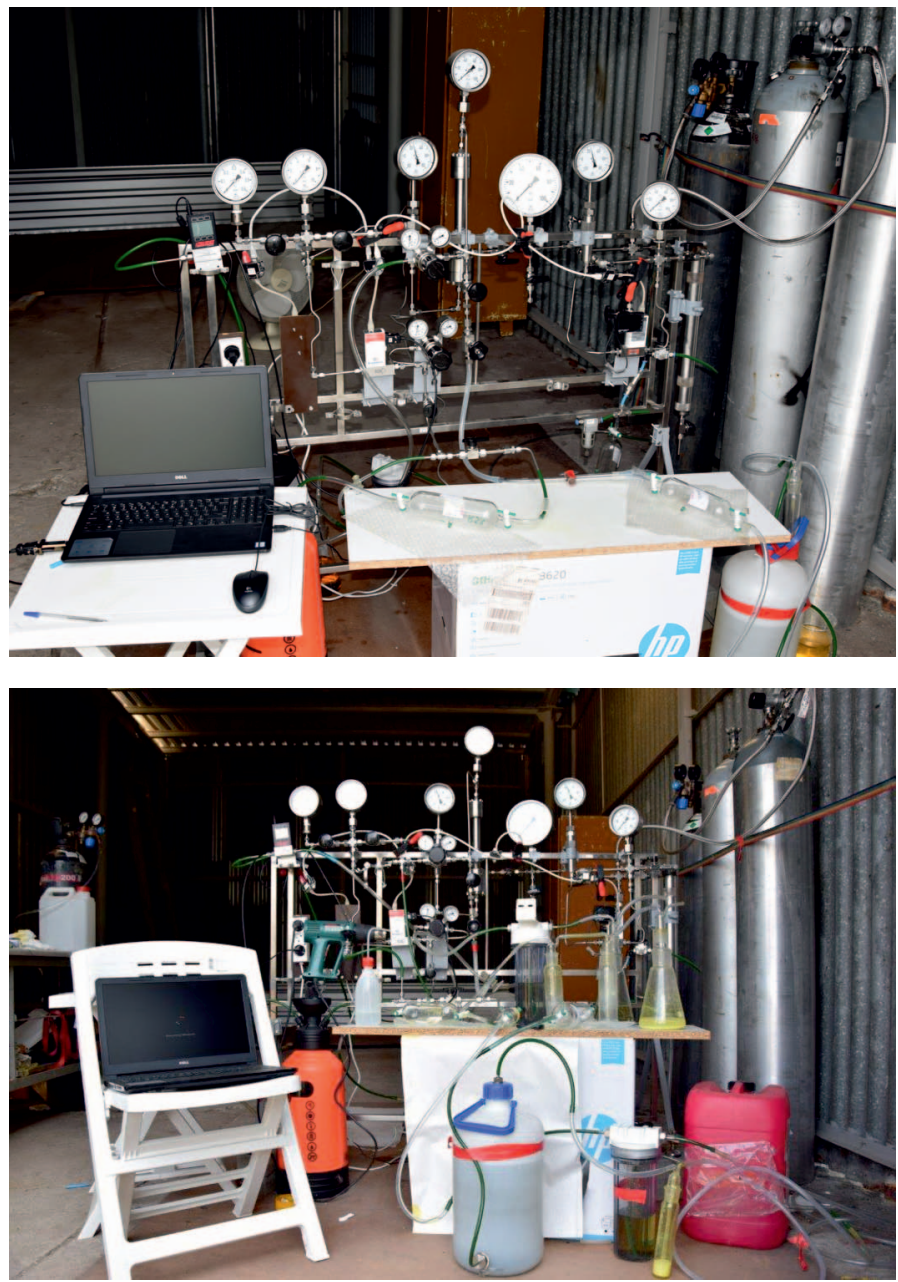

Fig. 5. Photos of the membrane gas separation test stand

\section{Testing procedure}

The $\mathrm{H}_{2} \mathrm{~S}-\mathrm{CH}_{4}$ separation tests started on a gas mixture with a very low hydrogen sulphide concentration of $0.28 \%$. At such an $\mathrm{H}_{2} \mathrm{~S}$ concentration, the permeate flow rate depends mainly on the methane flow rate, which accounts for the majority of the gas in the mixture, as shown in Figure 6. In these tests, measurements were made at 20 bar and 35 bar. As shown in Figure 6, the permeate flow rate increases as the pressure increases. At a pressure of $20 \mathrm{bar}$, the changes in the permeate flow rate depending on the inlet stream flow rate are not noticeable, while a slight increase in the permeate flow rate can be seen at a pressure of 35 bar. This is due to the visible presence of hydrogen sulphide (which penetrates through the membrane faster than methane).

The next two diagrams in Figures 7 and 8 show the changes of hydrogen sulphide concentrations in the product streams (P20, P35 - $\mathrm{H}_{2} \mathrm{~S}$ concentrations in the permeate, R20 and $\mathrm{R} 35-\mathrm{H}_{2} \mathrm{~S}$ concentrations in the retentate). 


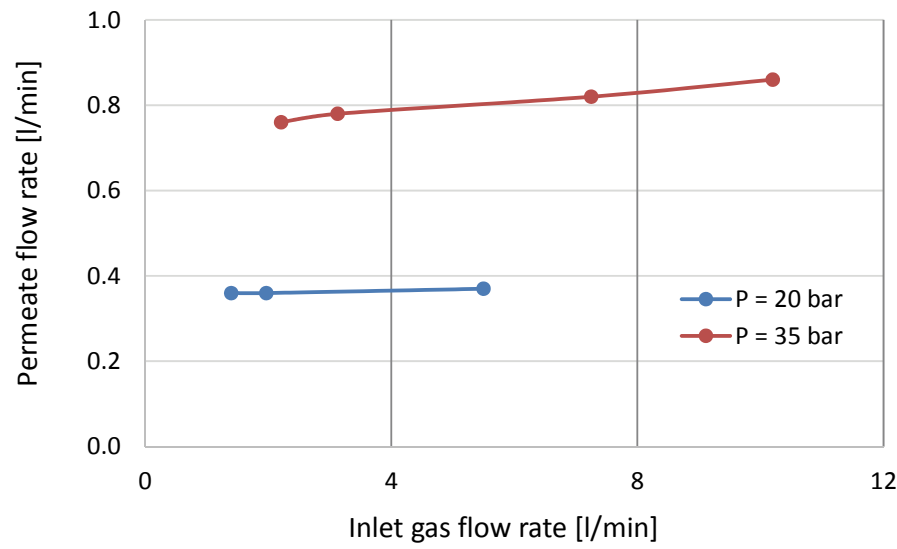

Fig. 6. The dependence of the permeate flow rate on the inlet gas flow rate for pressures: 20 and 35 bar

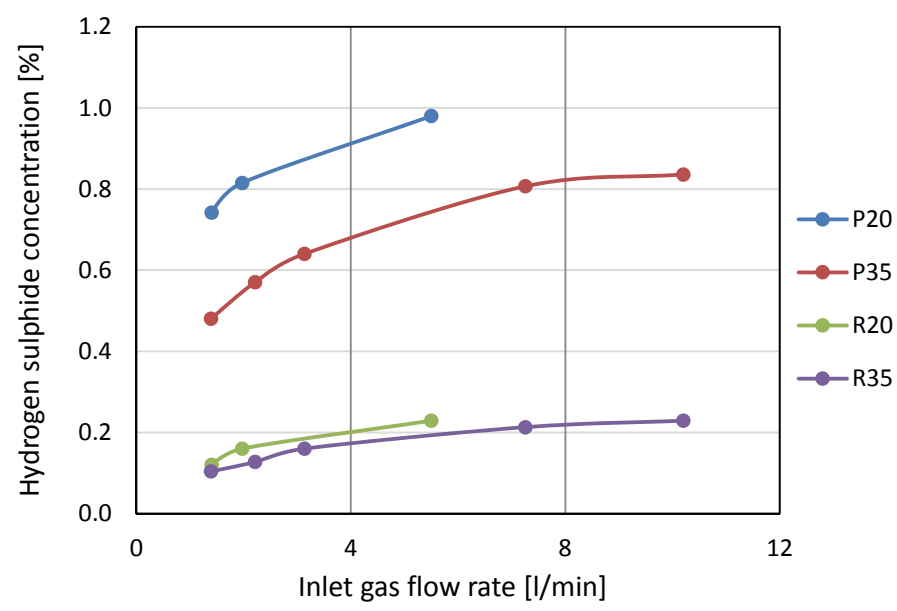

Fig. 7. The dependence of the hydrogen sulphide concentration in individual streams on the inlet gas flow rate for a pressure of 20 bar (P20 and R20) and 35 bar (P35 and R35)

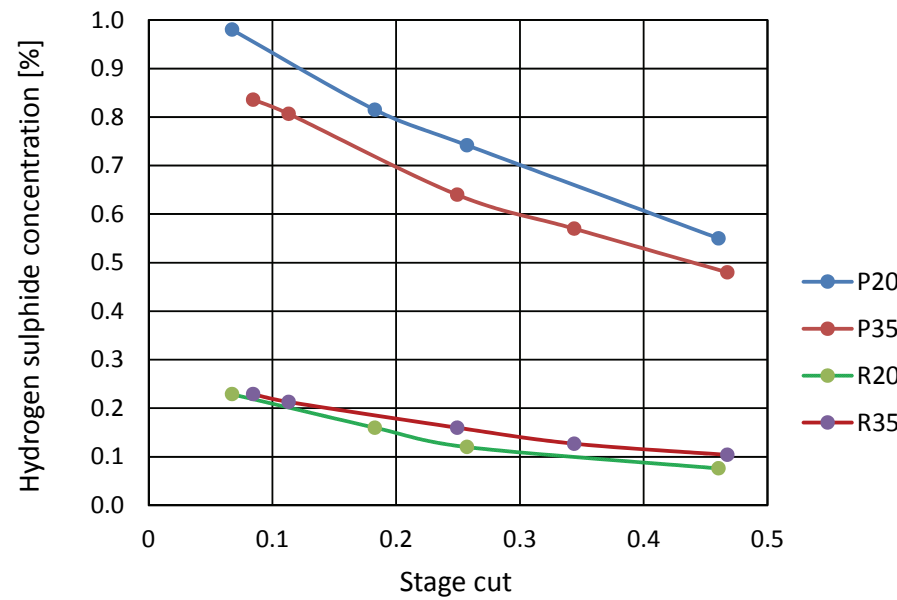

Fig. 8. The dependence of the hydrogen sulphide content in the permeate and retentate at 20 bar (P20 and R20) and 35 bar (P35 and R35) depending on the stage cut (the proportion of the permeate stream in the inlet gas)

The higher the inlet gas flow rate (and the lower the stage cut) is the higher the hydrogen sulphide content of both the streams is. For a pressure of 20 bar, the values of the hydro- gen sulphide concentration in the permeate are higher than for $35 \mathrm{bar}$, while the reverse is true of the level of $\mathrm{H}_{2} \mathrm{~S}$ in the retentate. For low stage cut values, the hydrogen sulphide content in the permeate increased more than three times (from $0.28 \%$ ). Based on the results above, the degree of hydrogen sulphide removal from the inlet gas was calculated, as shown in Figure 9.

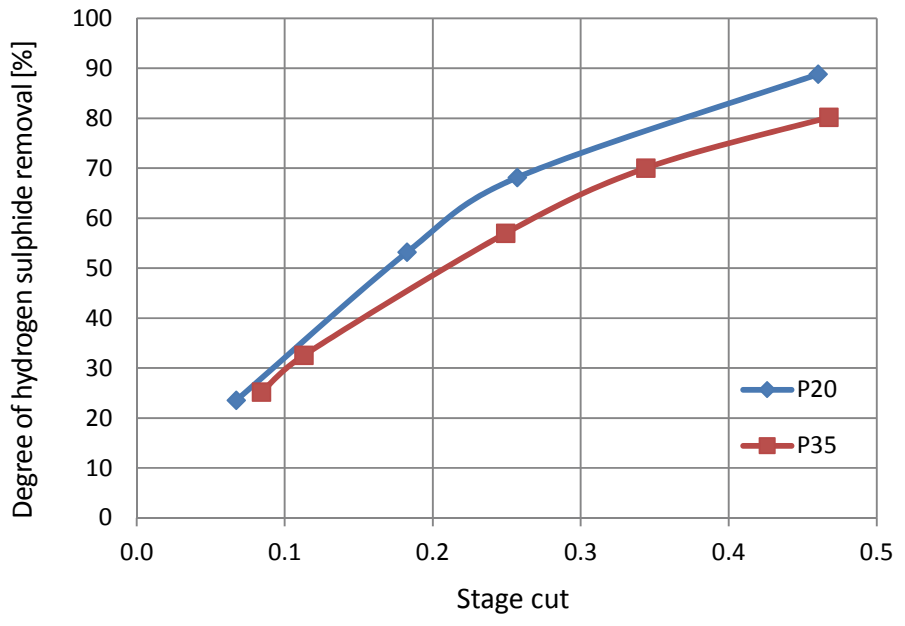

Fig. 9. The dependence of the degree of hydrogen sulphide removal from the inlet gas on the stage cut for the inlet gas pressure of 20 and 35 bar

As can be seen in Figure 9, with a longer gas contact time with the membrane (i.e. high stage cut values), the degree of removal of $\mathrm{H}_{2} \mathrm{~S}$ from the gas is high, but this happens at the expense of higher quantities of methane passing into the lowpressure permeate stream.

It should be remembered that while the process performance indicators may indicate their relative superiority at low pressures, the absolute amounts of hydrogen sulphide passing through the same membrane are higher at higher pressures. This is shown in Figure 10.

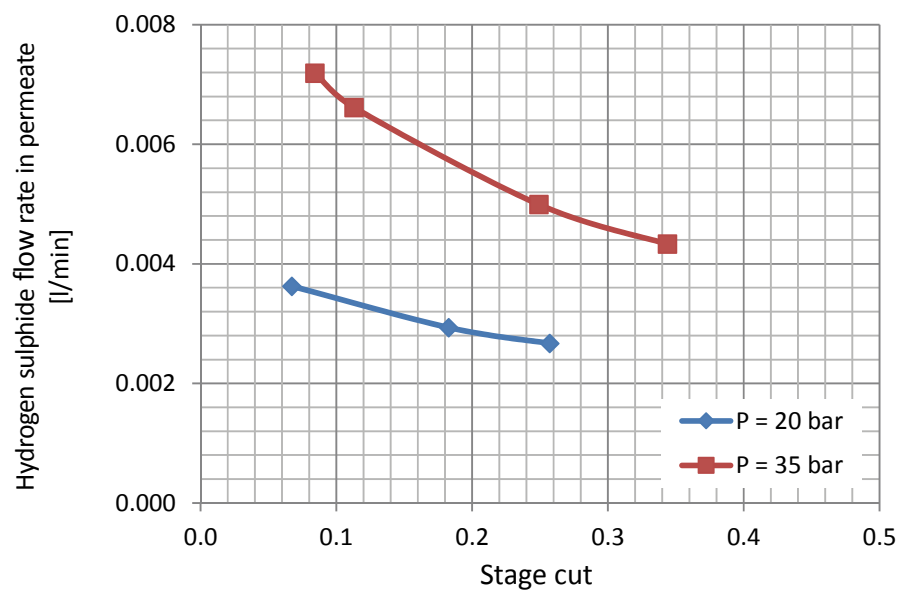

Fig. 10. The dependence of the quantity of the flowing hydrogen sulphide on the stage cut 
The actual amount of $\mathrm{H}_{2} \mathrm{~S}$ flowing through the membrane is the product of its concentration in the permeate and the permeate flow rate.

Further tests were carried out for $2.9 \%$ of hydrogen sulphide in the inlet gas at separation pressures of 20, 60 and 80 bar. The results of the separation are shown in Figure 11.

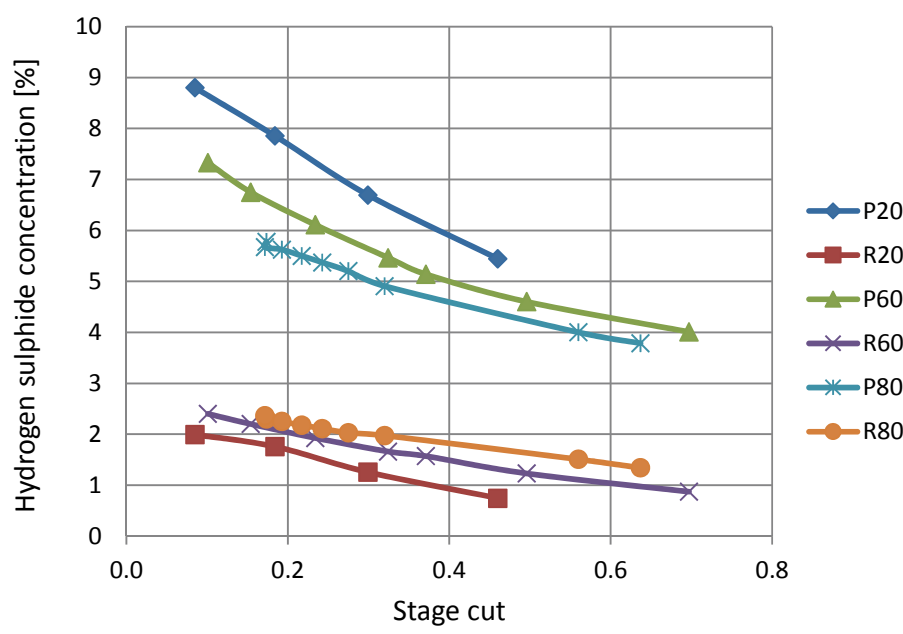

Fig. 11. The dependence of the hydrogen sulphide content in permeate and retentate at 20 bar (P20 and R20), 60 bar (P60 and R60) and 80 bar (P80 and R80)

As the tests show, the general trend of changes in concentrations of hydrogen sulphide in individual product streams is similar to that of the previous test series where the $\mathrm{H}_{2} \mathrm{~S}$ content was 10 times lower.

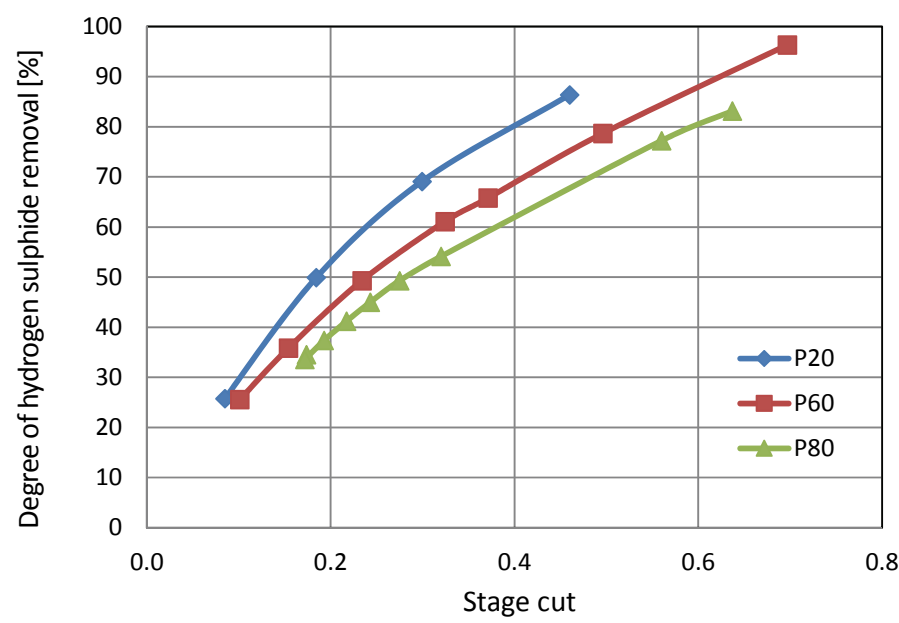

Fig. 12. The dependence of the degree of hydrogen sulphide removal from the inlet gas on the stage cut

The results of a series of separation tests on a polyimide membrane module for an inlet gas containing $7.5 \%$ of $\mathrm{H}_{2} \mathrm{~S}$ are shown in Figure 13.

The measurement results shown in Figure 13 were carried out for $10 \mathrm{bar}, 40 \mathrm{bar}$ and $80 \mathrm{bar}$. As can be seen from this diagram,

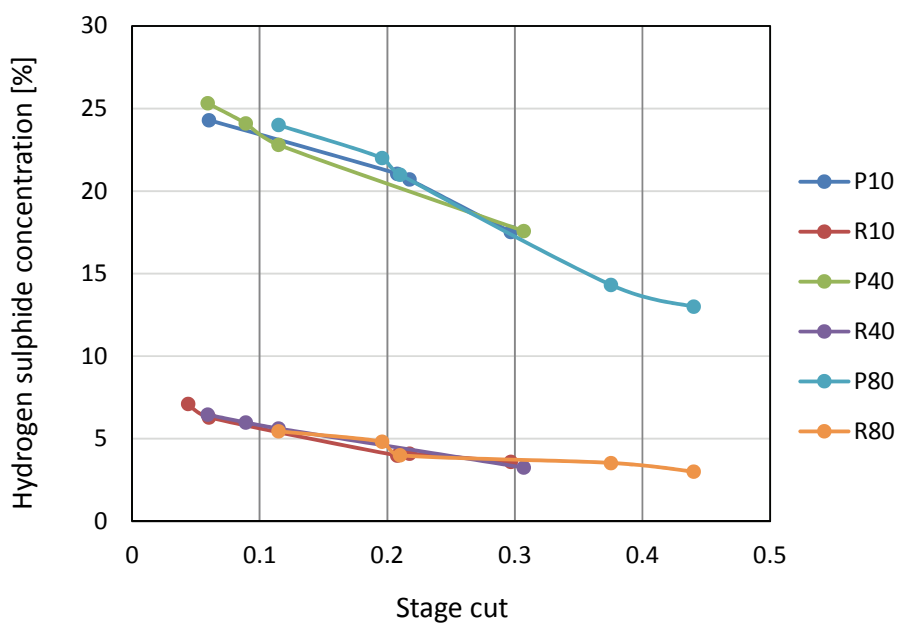

Fig. 13. The dependence of the hydrogen sulphide content in the permeate and retentate for 10 bar (P10 and R10), 40 bar (P40 and R40) and 80 bar (P80 and $\mathrm{R} 80)-7.5 \% \mathrm{H}_{2} \mathrm{~S}$ inlet gas

the differences between the measurements at different pressures are minimal, which sets them apart from the previous tests on gas mixtures with lower hydrogen sulphide content in the gas.

The last series of tests was performed for an inlet gas stream containing $17.9 \%$ of hydrogen sulphide and $82.1 \%$ of methane at different separation pressures. The measurment results for this gas is shown in Figure 14.

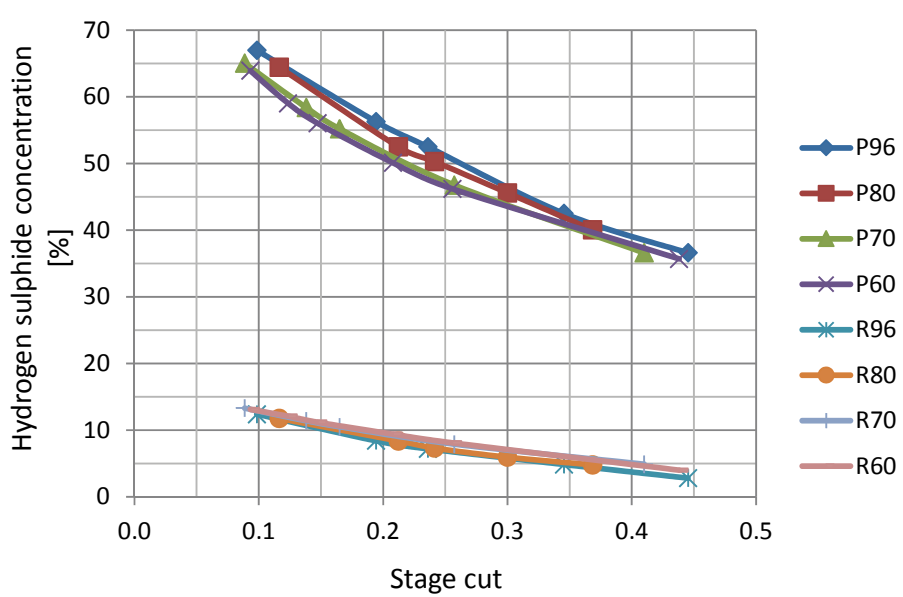

Fig. 14. The dependence of the hydrogen sulphide content in the permeate and retentate on the stage cut for the inlet gas pressure of 60 bar (P60 and R60), 70 bar (P70 and R70), 80 bar (P80 and R80) and 96 bar (P96 and R96). Inlet gas - 17,9\%.

Like for the inlet gas containing $7.5 \%$ of $\mathrm{H}_{2} \mathrm{~S}$, in the case of the $17.9 \%$ hydrogen sulphide gas shown in Figure 14, the differences in its content in the product streams at different pressures are small. However, it can be seen in the permeate that the increase in hydrogen sulphide concentration in the inlet gas caused a change in the trend in its content together with the pressure increase. For low stage cut values, the hydrogen sulphide content of the permeate exceeds $60 \%$. 
Changes in the hydrogen sulphide flow rate in the permeate depending on the stage cut are shown in Figure 15.

Figure 15 shows that the dependence of the hydrogen sulphide content on the flow rate depends less on the process pressure than in the previous tests with lower concentrations of hydrogen sulphide.

Fig. 15. The dependence of the quantity of flowing hydrogen sulphide in the permeate on the stage cut at pressures of 96, 89, 60 and 40 bar

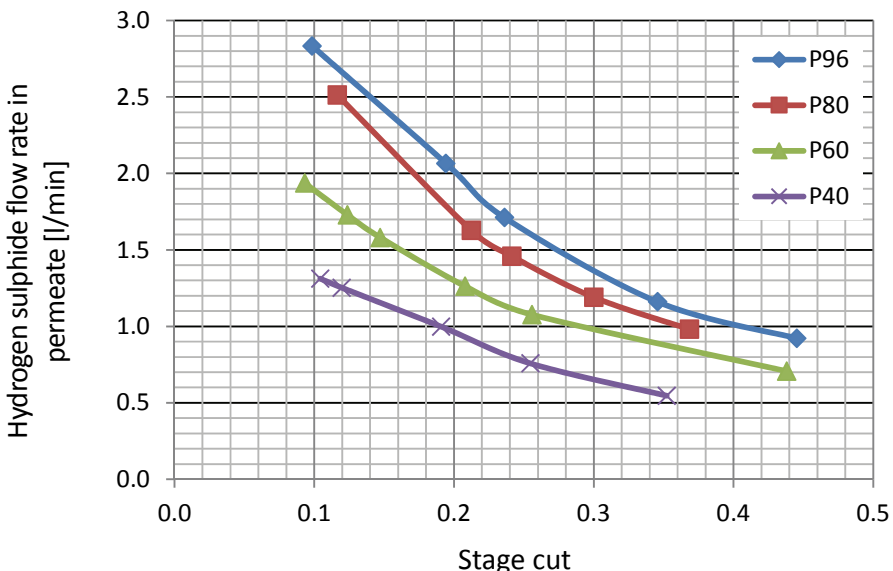

\section{Conclusions}

The tests were conducted for four $\mathrm{CH}_{4}-\mathrm{H}_{2} \mathrm{~S}$ gas mixtures with $0.28 \%, 2.9 \%, 7.5 \%$ and $17.9 \%$ hydrogen sulphide concentrations. Tests were carried out at various inlet gas pressures ranging from 10 bar to 96 bar. In the main part of the tests, permeate pressures were collected at a low excess pressure ( 0.06 to 0.1 bar), which was associated with the resistance to flow through the washers absorbing hydrogen sulphide. All the tests were carried out at $21 \div 22^{\circ} \mathrm{C}$.

The tests were carried out for different inlet gas flow rates with the stages cut values mostly ranging from 0.08 to 0.45 , which means that $8 \div 45 \%$ of the inlet gas stream passed through the membrane.

In all the tests, the permeate flow rate increases as the pressure rises. Similarly, the permeate flow rate increases with an increase in the flow rate of the high-pressure stream, with the rate of this increase being higher for higher hydrogen sulphide concentrations. The permeate flow rate decreases with the increase in the stage cut, which is due to the decrease in the content of the faster-permeating component $\left(\mathrm{H}_{2} \mathrm{~S}\right)$ along the capillaries in the counter-current membrane module. According to the analysis of the tests, as the $\mathrm{H}_{2} \mathrm{~S}$ content in the inlet gas increases, methane losses decrease, e.g. for the stage cut of 0.2 , regardless of the pressure conditions of the conducted tests (from $20 \%$ for $0.28 \% \mathrm{H}_{2} \mathrm{~S}$ concentration to approx. $12 \div 13 \%$ for $17.9 \%$ of $\mathrm{H}_{2} \mathrm{~S}$ ).

In the case of the desulphurisation of an actual natural gas, the mixture will also contain other components that pass through the membrane together with methane. This is especially true for nitrogen and carbon dioxide, which permeate through the polyimide membrane much faster than methane. This means that in the process of desulphurisation of actual natural gas on membranes, the methane losses will be proportionally lower because it will be $\mathrm{N}_{2}$ and $\mathrm{CO}_{2}$ (rather than methane) that will pass into the permeate to a large extent.

To sum up, membrane techniques can be successfully applied in the natural gas desulphurisation process at the initial stage of mass removal of hydrogen sulphide prior to the process of thorough purification by other methods.

Please cite as: Nafta-Gaz 2018, no. 7, pp. 511-517, DOI: 10.18668/NG.2018.07.04

Article contributed to the Editor 11.12.2017. Approved for publication 2.07.2018.

The article was written based on the statutory paper entitled: Określenie możliwości separacji siarkowodoru ze strumienia gazów na membranach poliimidowych (Determination of the possibility of hydrogen sulphide separation from the gas stream on polyimide membranes) - INiG - PIB paper at the request of the Ministry of Science and Higher Education; order number 0049/KE, archival number KE-4101-0036/17.

\section{Literature}

[1] Ahmad F., Lau K.K., Shariff A.M., Murshid G.: Process simulation and optimal design of membrane separation system for $\mathrm{CO}_{2}$ capture from natural gas. Computers and Chemical Engineering 2012, vol. 36, pp. 119-128.

[2] Alcheikhhamdon Y., Hoorfar M.: Natural gas purification from acid gases using membranes. Chemical Engineering and Processing: Process Intensification 2017, vol. 120, pp. 105-113.

[3] Askari M., Chua M.L., Chung T.S.: Permeability, solubility, diffusivity and PALS data of cross-linkable 6FDA-ba- sed copolyimides. Ind. Eng. Chem. Res. 2014, vol. 53, no. 6, pp. 2449-2460.

[4] Baker R.: Membrane technology and applications. The McGraw-Hill, USA 2000, ISBN 0-07-135440, pp. 301-353.

[5] Baker R.W.: Future Directions of Membrane Gas Separation Technology. Ind. Eng. Chem. Res. 2002, vol. 41, pp. 1393-1411.

[6] Bernardo P., Drioli E., Golemme G.: Membrane Gas Separation: A review/State of the Art. Ind. Eng. Chem. 2009, vol. 48, pp. 4638-4663. 
[7] Bhide B.D., Stern S.A.: Membrane processes for the removal of acid gases from natural gas. Journal of Membrane Science 1993, vol. 81, pp. 209-237.

[8] Chatterjee G., Houde A., Stern S.: Poly (ether urethane) and poly (ether urethane urea) membranes with high $\mathrm{H}_{2} \mathrm{~S} / \mathrm{CH}_{4}$ selectivity. Journal of Membrane Science 1997, vol. 135, no. 1, pp. 99-106.

[9] Chenar M.P., Savoji H., Soltanieh M., Matsuura T., Tabe-Mohammadi A.: Removal of hydrogen sulfide from metane using commercial polyphenyle oxide and Cardo-type polyimide hollow fiber membranes. Korean J. Chem. Eng. 2011, vol. 28, no. 3, pp. 902-913.

[10] Cnop T., Dormund D., Schott M.: Continued Development of gas separation membranes for higly sour service. Materiały prezentacji UOP LLC, 2016.

[11] Favvas E.P., Katsaros F.K., Papageorgiou S.K., Sapalidis A.A., Mitropoulos A.C.: A review of the latest development of polyimide based membranes for $\mathrm{CO}_{2}$ separations. Reactive and Functional Polymers 2017, vol. 120.

[12] Gabrielli P., Gazzani M., Mazzotti M.: On the optimal design of membrane based gas separation processes. Journal of Membrane Science 2017, vol. 526, pp. 118-130.

[13] George G., Bhoria N., AlHallaq S., Abdala A., Mittal V.: Polymer membranes for acid gas removal from natural gas. Separation and Purification Technology 2016, vol. 158, pp. 333-356.

[14] Ghasemzadeh K., Jafari M., Sari A., Babalou A.A.: Performance investigation of membrane process in natural gas sweetining by membrane process: modeling study. Journal of Chemical Product and Process Modeling 2016, vol. 11, pp. 2015-0054.

[15] Hao J., Rice P.A., Stern S.A.: Upgrading low-quality natural gas with $\mathrm{H}_{2} \mathrm{~S}$ - and $\mathrm{CO}_{2}$-selective polymer membranes: Part II. Process design, economics, and sensitivity study of membrane stages with recycle streams. Journal of Membrane Science 2008, vol. 320, no. 1-2, pp. 108-122.

[16] Holewa J., Szlęk M.: Ocena jakości gazów palnych. Nafta-Gaz 2013, no. 6, pp. 450-454.

[17] Hosseini S.S., Roodashti S.M., Kundu P.K., Tan, N.R.: Transport Properties of Asymmetric Hollow Fiber Membrane Permeators for Practical Applications: Mathematical Modelling for Binary Gas Mixtures. Canadian Journal of Chemical Engineering 2015, vol. 93, no. 7, pp. 1275-1287.

[18] Huang Y., Merkel T.C., Baker W.: Pressure ratio and impact on membrane gas separation processes. Journal of Membrane Science 2014, vol. 1463, pp. 33-40.

[19] Janocha A.: Badania obniżania zawartości $\mathrm{CO}_{2} w$ gazie ziemnym przy użyciu membrany poliimidowej. Nafta-Gaz 2016, no. 3, pp. 186-191, DOI: 10.18668/NG.2016.03.05.

[20] Janocha A.: Określenie możliwości odwadniania gazu ziemnego na membranach polimerowych. Nafta-Gaz 2017, no. 7, pp. 502-509, DOI: 10.18668/NG.2017.07.08.

[21] Klass D.L., Landahl C.D.: Gas sweetening by membrane permeation. US Patent 4561864, 1985 (2006).

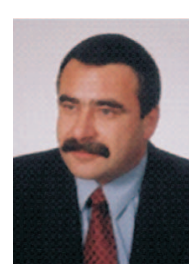

Andrzej JANOCHA PhD

Assistant Professor

Department of Exploitation Technology

for Reservoir Fluids

Oil and Gas Institute - National Research Institute

ul. Lubicz 25 A, 31-503 Kraków

E-mail: andrzej.janocha@inig.pl
[22] Koros W.J., Mahajan R.: Pushing the limits on possibilities for large scale gas separation: which strategies? Journal of Membrane Science 2000, vol. 175, no. 2, pp. 181-196.

[23] Kraftschik B., Koros W.J., Johnson J.R.: Dense film polyimide membranes for aggressive sour gas feed separations. Journal of Membrane Science 2013, vol. 428, no. 1, pp. 608-619.

[24] Lau C.H., Li P., Li F.Y., Chung T.S., Paul D.R.: Reverse-selective polymeric membranes for gas separations. Progress In Polymer Science 2013, vol. 38, no. 5, pp. 740-766.

[25] Lin H.: High-Performance Polymer Membranes for natural gas sweetening. Advances Materials 2006, vol. 18, pp. 39-44.

[26] Liu G., Li N., Miller S.J., Kim D., Yi S., Labreche Y., Koros W.J.: Molecularly Designed Stabilized Asymmetric Hollow Fiber Membranes for Aggressive Natural Gas Separation. Angewandte Chemie 2016, vol. 128, no. 44, pp. 13958-13962.

[27] Niknejad S.M.S., Savoji H., Pourafshari Chenar M., Soltanieh M.: Separation of $\mathrm{H}_{2} \mathrm{~S}$ from $\mathrm{CH}_{4}$ by polymeric membranes at different $\mathrm{H}_{2} \mathrm{~S}$ concentrations. International Journal of Environmental Science and Technology 2017, vol. 14, nr 2, pp. 375-384.

[28] Pandey P., Chauhan R.S.: Membranes for gas separation. Progress in Polymer Science 2001, vol. 26, no. 6, pp. 853-893.

[29] Piskowska-Wasiak J.: Uzdatnianie biogazu do parametrów gazu wysokometanowego. Nafta-Gaz 2014, no. 2, pp. 94-105.

[30] Sanders D.F., Guo R., Smith Z.P., Stevens K.A., Liu Q., McGrath J.E., Paul D.R., Freeman B.D.: Influence of polyimide precursor synthesis route and ortho-position functional group on thermally rearranged (TR) polymer properties. Journal of Membrane Science 2014, vol. 463, pp. 73-81.

[31] Scholes C.A., Stevens G.W., Kentish S.E.: Membrane gas separation applications in natural gas processing. Fuel 2012, vol. 96, pp. 15-28.

[32] Szwast M.: Membrany polimerowe do rozdzielania gazów. Przemysł Chemiczny 2012, vol. 91, no. 7, pp. 1356-1361.

[33] Szwast M., Janocha A.: Research on supported liquid membrane to adjust (reduce) the nitrogen content in natural gas. Proceedings The $6^{\text {th }}$ Membrane Conference of Visegrad Countries 15-19.09.2013, Warsaw, pp. 252-255.

[34] UBE company information materials.

[35] Vaughan J.T., Koros W.J.: Analysis of feed stream acid gas concentration effects on the transport properties and separation performance of polymeric membranes for natural gas sweetening: A comparison between a glassy and rubbery polymer. Journal of Membrane Science 2014, vol. 465, pp. 107-116.

[36] White L.S., Blinka T.A., Kloczewski H.A., Wang I.: Properties of a polyimide gas separation membrane in natural gas streams. Journal of Membrane Science 1995, vol. 103, pp. 73-76.

\section{Legal and normative acts}

[37] PN-C 94752:2011 Gaz ziemny. Jakość gazu w sieci przesyłowej.

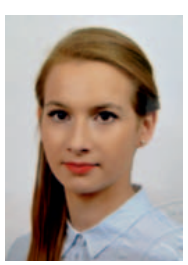

Katarzyna WOJTOWICZ MSc.

Engineering and technical specialist in the Department of Exploitation of Reservoir Fluids Technology Oil and Gas Institute - National Research Institute ul. Lubicz $25 \mathrm{~A}$

31-503 Kraków

E-mail: katarzyna.wojtowicz@inig.pl 